\title{
Jorden under forandring - kontinenter på vandring
}

\section{Af geolog Ulla V. Hjuler, GeologiskNyt}

Jordens yderste $100 \mathrm{~km}$ er dækket afkontinental-og oceanbundsplader, der bevæger sig i forhold til hinanden. Pladerne kan bevæge sig væk fra hinanden, passere forbi hinanden eller støde sammen. Ved Sumatra var konsekvensen af to pladers langvarige "sammenstød" og stress-opbygning et meget voldsomt jordskælv efterfulgt af flere store efterskælv, der opstod i subduktionszonen ved Sunda-graven i Det Indiske Ocean.

Sumatra-jordskælvet er en direkte konsekvens af pladetektonikken. Teorien om pladetektonik blev fremsat så sent som i 1960erne. Overordnet set går teorien ud på, at oceanbundsplader og kontinentalplader som følge af konvektion i kappen er i stadig bevægelse. Langs pladernes kanter kan der opbygges store spændinger, der udløses som jordskælv, hvilket d. 26. december jo er et frygtindgydende eksempel på. Lad os derfor i det følgende kigge på jordens opbygning og på de processer, der fører til katastrofer som den, der fandt sted i Det Indiske Ocean.

\section{Jordens opbygning}

Jorden er opbygget som et løg. Inderst findes den fast kerne. Den er omgivet af den flydende kerne, som primært består af jern. Kernen omgives af den faste kappe, som har en lavere massefylde end kernen. Kappen er rig på grundstofferne ilt, silicium, magnesium og jern. Den inddeles i 3 lag, nederst mesosfæren, derefter astenosfæren, og øverst litosfæren. Denne 3-deling afspejler en variation i kappens elastiske egenskaber, som igen afspejler temperatur-fordelingen i kappen. Det midterste lag, astenosfæren, som strækker sig fra ca. $350 \mathrm{~km}$ til mellem 100 og $200 \mathrm{~km}$ under Jordens overflade, er relativt svagt, idet temperaturen her er tæt på smeltepunktet.

Mesosfæren og litosfæren er stærke og elastisk stive lag, men på trods heraf er alle 3 lag i kappen i konstant, meget langsomt krybende bevægelse, lidt ligesom glas, som jo er en væske, der blot flyder meget langsomt.

Den yderste skal i løget er skorpen, som også er fast og udgør den øverste del af litosfæren. Skorpen har den laveste masse-

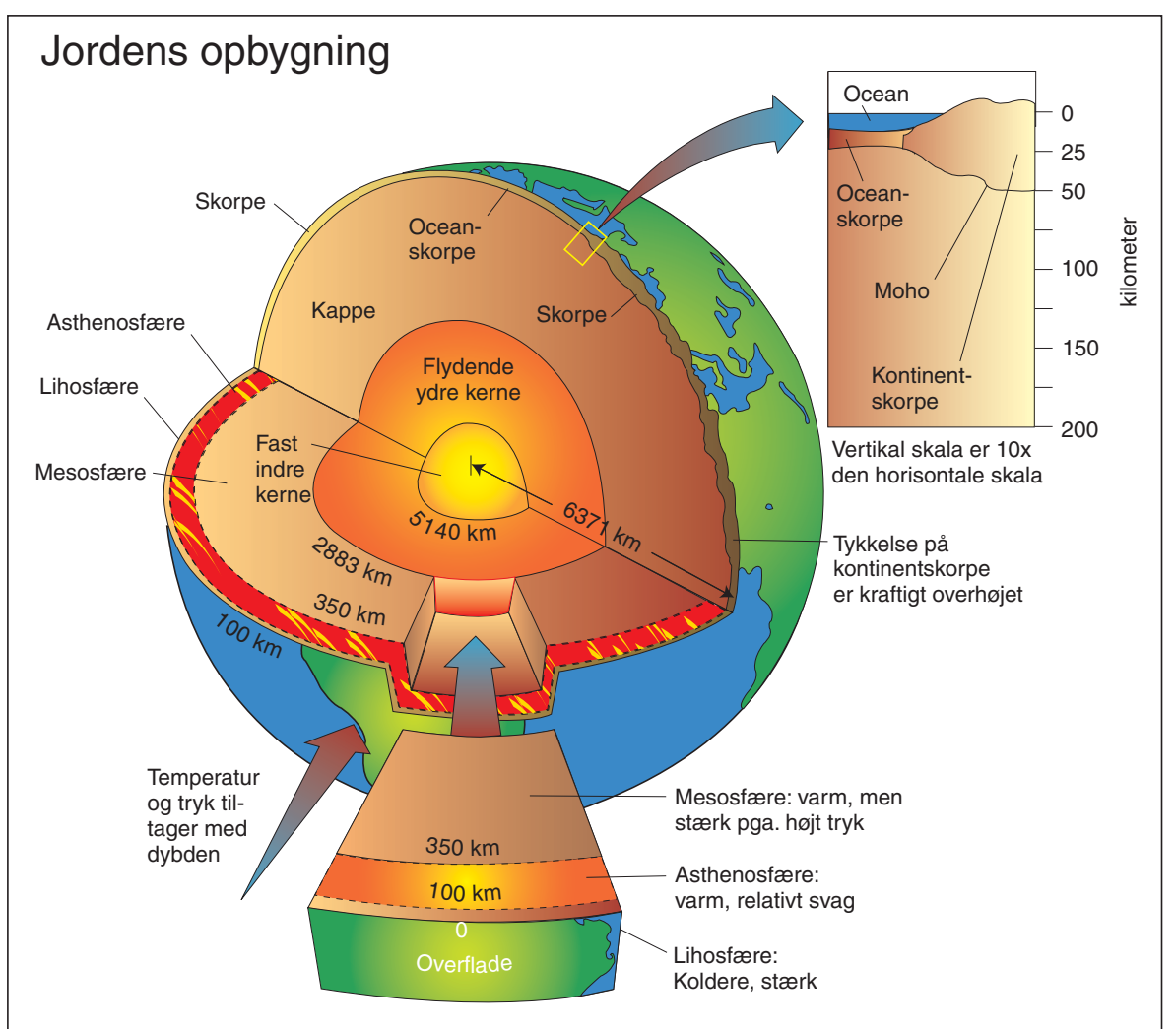

Jordens opbygning i lag. Tykkelsen på de forskellige lag er angivet. (Grafik: Forfatteren modificeret efter Skinner \& Porter)

fylde og består fortrinsvis af ilt, silicium, aluminium, calcium, natrium, kalium og jern. Skorpen findes i 2 former, dels som oceanskorpe, som er 5 til $8 \mathrm{~km}$ tyk og næsten helt består af vulkanske bjergarter, dels som kontinentskorpe, der varierer i tykkelse fra 25 til $70 \mathrm{~km}$ og består af en stor variation af bjergarter (granit, gnejs m.m.)

\section{Konvektion i kappen}

Jordens indre bevæger sig hele tiden - hvilket vi kan mærke, når der sker et jordskælv. Konvektion (flytning af varme vha. strømninger) i kappen sørger for, at varmt og relativt let materiale bevæger sig opad og erstattes af koldt og tungere materiale, der bevæger sig nedad i cirkulerende bevægelser (figuren til højre). Jordens kerne er mindst $5.000{ }^{\circ} \mathrm{C}$ varm, og denne varme, der skyldes radioaktive henfald, afgives til det overliggende lag, kappen. Varme bjergarter stiger således op fra Jordens indre, og bjergarter afkøles i den øvre del af kappen og synker, hvorved konvektionen opstår. Der dannes således flere konvektionsceller i kappen, og lithosfærepladernes bevægelse er en direkte afspejling af konvektionen.
Pladetektonik - pladernes bevægelse Pladetektonik er studiet af pladernes bevægelse og deformation. Lithosfæren udgøres af forskellige plader (figuren næste side øverst til venstre), der har varierende størrelse - nogle er uhyre store som fx Stillehavspladen og den afrikanske plade, andre er "små"som Burma-og Sunda-pladerne. Konvektionen bevirker, at pladerne bevæger sig med forskellige hastigheder-nogle med hastigheder på op til $12 \mathrm{~cm} / \mathrm{a} r-o g$ de bevæger sig ikke i samme retning. Hvis to plader bevæger sig væk fra hinanden, som det er illustreret på figuren, er der tale om diver-

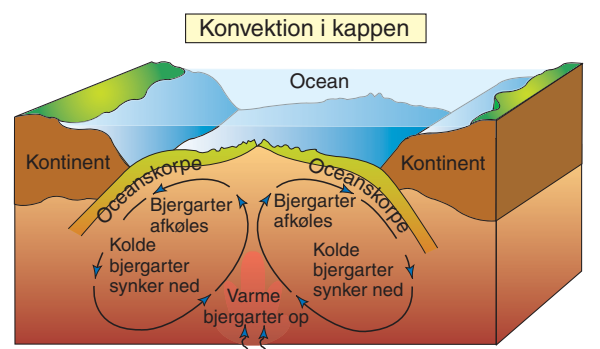

Konvektion i kappen er årsag til lithosfarepladernes bevagelse. (Garfik: Forfatteren modificeret efter Skinner \& Porter) 


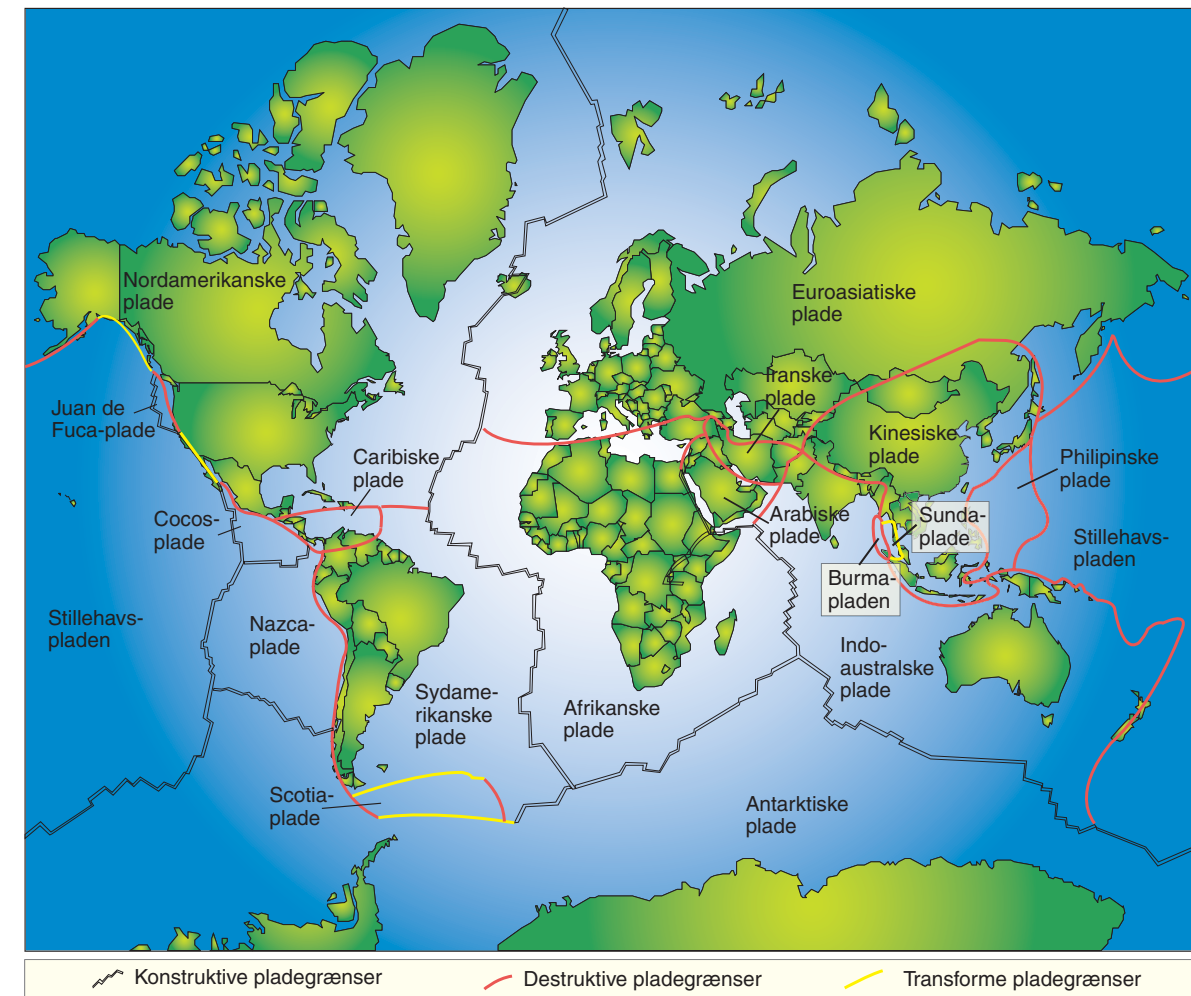

Fordelingen af Jordens plader og de forskellige typer pladegranser. Burma-og Sunda-pladerne er markeret. (Grafik: Forfatteren)

gente eller konstruktive pladegrænser. To plader kan også bevæge sig forbi hinanden, hvilket giver transforme pladegrænser. Bevæger nogle af pladerne sig mod hinanden kaldes pladegrænserne konvergente eller destruktive. Denne proces medfører enten, at den ene plade bevæger sig ned under den anden, altså en subduktionszone (som ved Sumatra), eller at de to plader kollidererdvs. en kollisionszone.

\section{Konstruktive pladegrænser}

Konstruktive pladegrænser findes, hvor to plader bevæger sig væk fra hinanden - herved stiger magma op fra kappen og danner ny oceanskorpe. Den nok mest kendte spredningszone er Den Midtatlantiske Ryg, der løber i nord-sydgående retning gennem Atlanterhavet og midt igennem Island. Spredningshastigheden er gennemsnitligt på 2,5 $\mathrm{cm} /$ år, hvilket kan synes langsomt, men det giver en spredning på $25 \mathrm{~km}$ på 1 mio. år!

Halvdelen af Island er en del af den nordamerikanske plade, der bevæger sig $\mathrm{i}$ vestlig retning, og den anden halvdel er en del af den euroasiatiske plade, der bevæger sig i østlig retning. Pladebevægelserne medfører kraftig vulkanisme bl.a. fra vulkanerne Krafla og Grímsvötn. Således bliver Island større og større, da øen ikke deles op i to, men vokser, ved at der fyldes op med lava i spredningszonen.

Et andet eksempel på en aktiv spredningszone ser vi i Østafrika (den afrikanske plade), hvor Saudi-Arabien (den arabiske plade) "trækkes" væk fra det afrikanske kontinent, hvorved Det Røde Hav er dannet. En interessant detalje er i øvrigt hér skabelsen af en såkaldt triple junction, hvor Det
Røde Hav møder Adenbugten, der ligger i forlængelse af Den Afrikanske Riftzone. En triple junction er et punkt, hvor tre plader mødes; hér den somaliske del af den afrikanske plade, den nubiske del af den afrikanske plade samt den arabiske plade.

\section{Transforme pladegranser}

Ved disse zoner passerer to plader forbi hinanden, og da pladerne ikke er "glatte" på siderne, opstår der forkastninger og i den forbindelse ofte jordskælv. En del transforme forkastninger findes på havbunden, men en ganske kendt forkastning ligger som bekendt på land, nemlig San Andreas-forkastningen i Californien - den fortsætter dog ud i Stillehavet. Forkastningen, der er ca. 1.300 km lang, løber ca. nord-syd og adskiller den nordamerikanske plade i øst, hvor San Francisco ligger, fra Stillehavspladen i vest, hvor Los Angeles ligger. Stillehavspladen bevæger sig mod nord, mens den nordamerikan-

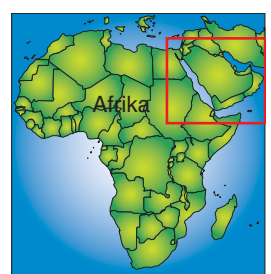

En triple junction betegner et punkt, hvor tre plader mødes. Her den afrikanske (nubiske) plade, den arabiske plade og den somaliske del af den afrikanske plade. Den arabiske plade og den nubiske plade bevager sig vak fra hinanden, hvilket medfører vulkanisme (Grafik: Forfatteren modificeret efter figur på http://pubs.usgs.gov)

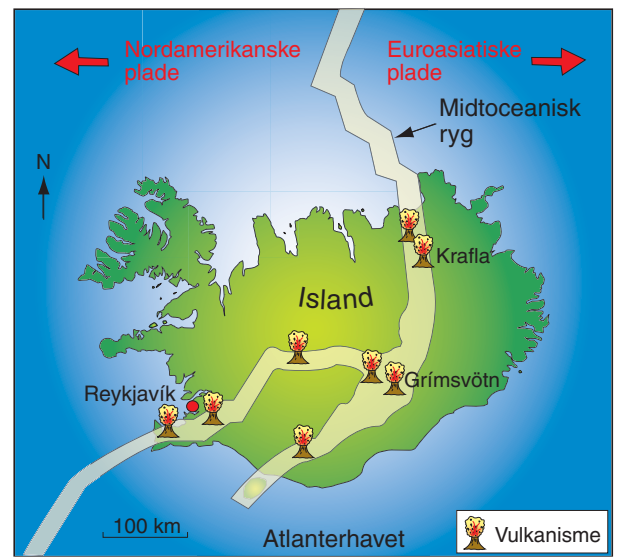

Den Midtatlantiske Ryg løber midt igennem Island - da den nordamerikanske plade bevager sig vak fra den euroasiatiske plade, opstår der kraftig vulkanisme i spredningszonen. (Grafik: Forfatteren)

ske plade bevæger sig i sydlig retning, og dette giver ophav til en del jordskælvsaktivitet $\mathrm{i}$ området. Bevægelseshastigheden er ca. $6 \mathrm{~cm} / \mathrm{år}$, dvs. om 10-15 mio. år ligger Los Angeles ved siden af San Francisco. Det største historiske jordskælv fandt sted i 1906 og havde en styrke på 8,3 på Richterskalaen. Omkring 700 mennesker omkom. I 1940 forekom et skælv på 7,1 langs en på daværende tidspunkt ukendt forkastning ved Imperial Valley. Faktisk har der vist sig at være en hel del større og mindre forkastninger langs med San Andreas-forkastningen både parallelt med hovedforkastningen og vinkelret på den (figuren nederst næste side).

\section{Destruktive grænser - subduktion}

Der findes tre typer subduktionszoner: ocean-kontinentkollision, kontinent-kontinetkollision og ocean-oceankollision.

Ocean-kontinentkollision: På kortet over plader kan man se, at den oceaniske Nazcaplade bevæger ind i den kontinentale del af den sydamerikanske plade ved Peru-Chilegraven. Da Nasca-pladen består af oceanskorpe, der er tyndere end den kontinentale sydamerikanske plade, subduceres den derfor ned i asthenosfæren. Den overliggende plade løftes op, og herved er de imponerende Andes-bjerge dannet. Pga. den hastighed, hvormed bjergkædedannelsen sker, er

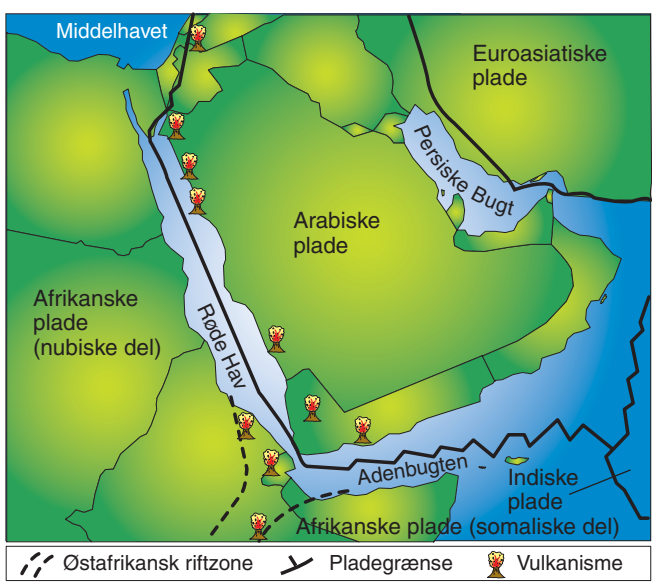




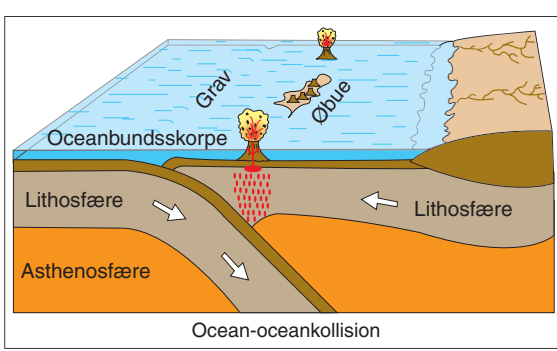

Ocean-oceankollision. Ved subduktionen dannes en grav og ofte en øbue. (Grafik: Forfatteren modificeret efter figur fra www. usgs.gov)

området udsat for kraftige jordskælv.

Selvom Nazca-pladen bevæger sig relativt jævnt og kontinuert nedad, brækker den subducerede plade op i mindre stykker, der kan sætte sig fast $\mathrm{i}$ længere tid for så pludselig at frigives og forårsage voldsomme jordskælv. Således rystede et jordskælv på 8,3 La Paz i Bolivia i 1994. Det var et såkaldt dybt jordskælv i 636 kilometers dybde, og netop pga. dybden var skaden ikke så stor. Kontinent-kontinentkollision: Når to kontinenter støder sammen, vil de bukkes, foldes og skubbes opad og til siden. Da Indien for ca. 50 mio. år siden kolliderede med Asien, medførte det, at den euroasiatiske plades skorpe blev "krøllet sammen" og presset op over den indiske plades skorpe. Efter millioner af år med et langsomt, men vedvarende tryk er Himalaya-bjergene presset op i deres nuværende højde på knap 9 $\mathrm{km}$. Undervejs blev Thetys-havet, som lå syd for Asien og nord for Indien, lukket som følge af Indiens aggressive fremmarch med en hastighed på $15 \mathrm{~cm} /$ år og med voldsom vulkansk aktivitet i det sydlige Tibet til følge ved subduktionen af oceanskorpen.

I de mere "hjemlige" egne har vi dannel-
Konstruktive pladegrænser

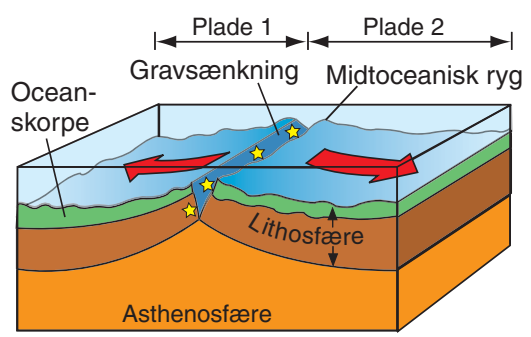

Destruktive pladegrænser (Kontinent-kontinentkollision)

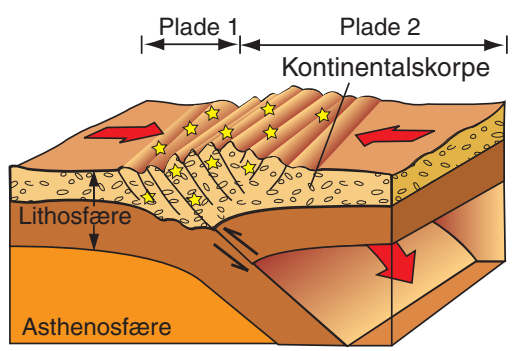

Destruktive pladegrænser (Ocean-kontinentkollision)

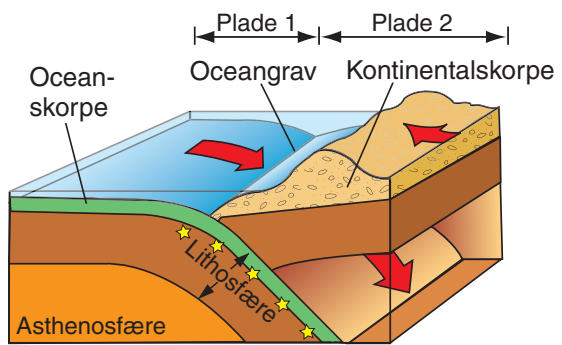

Transform forkastning

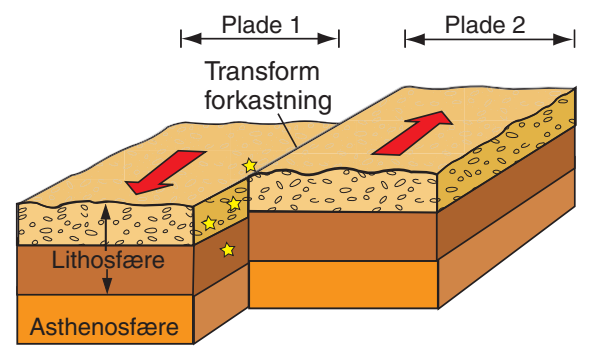

Forskellige typer pladegrcenser. Stjerner markerer mulige jordskcelvszoner. (Grafik: Forfatteren modificeret efter Skinner \& Porter)

sen af de centrale alper under den alpine orogenese (dvs. bjergkædedannelsen) (begyndende for ca. 100 mio. år siden), hvor den euroasiatiske plade kolliderede med den afrikanske plade.

Ocean-oceankollision: Som regel subduceres den ene plade ned under den anden, og ved denne proces kan der dannes en grav (trench) som fx Marianergraven, der er omkring $11 \mathrm{~km}$ dyb. Det er Stillehavspladen, som er blevet relativt stor, kold og ustabil,

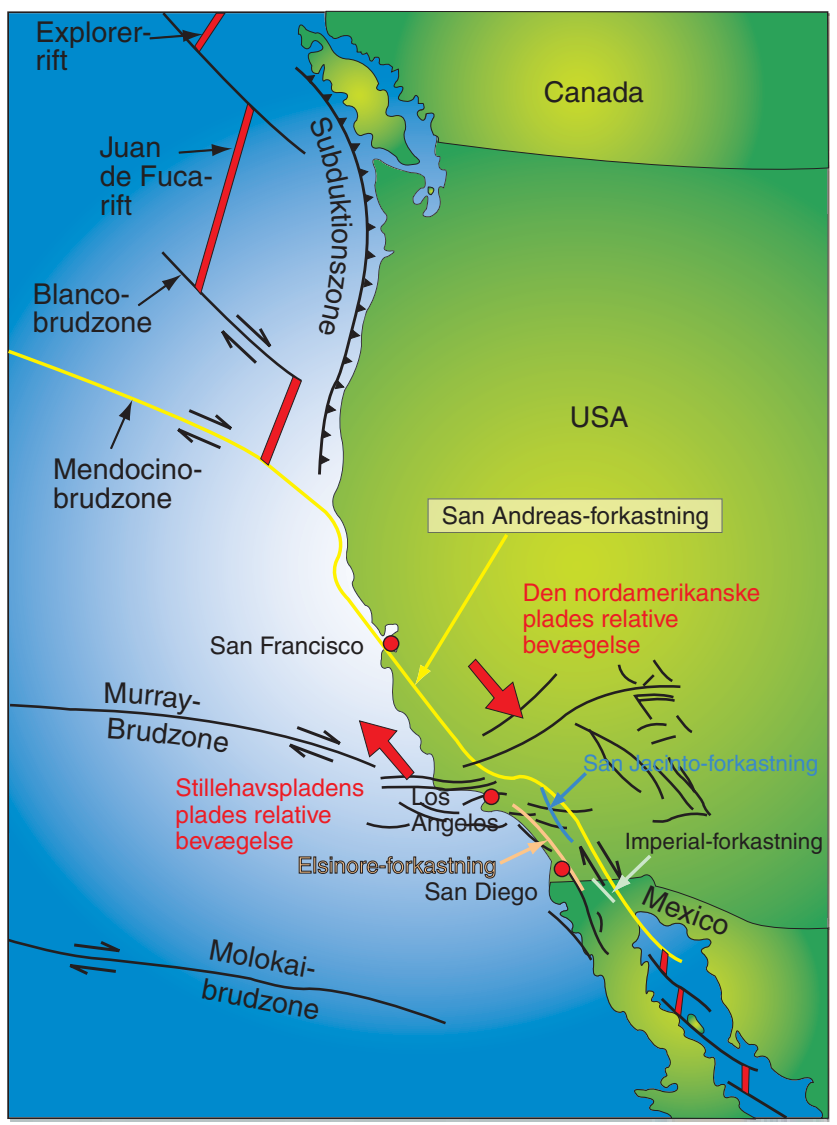

Kortet viser San Andreasforkastningen og 3 andre store forkastninger: Imperial-forkastningen (lysegrøn), Elsinore-forkastningen (orange) og San Jacinto-forkastningen (blå). Desuden er et større antal mindre forkastninger indtegnet med sort. (Grafik: Forfatteren) som synker ned under den filippinske plade. Herved kan der også opstå submarin vulkansk aktivitet, som efter lang tid resulterer i en vulkansk øbue. Opsmeltning af den subducerede plade og/eller den overliggende oceanskorpe danner øbuen, og den mængde stress, der opstår i forbindelse med subduktionen, er årsag til middelstærke til voldsomme jordskælv. Det er også denne proces, der var årsagen til jordskælvet i Det Indiske Ocean.

\section{Jordskælvet ved Sumatra}

På 2. juledag i 2004 opstod et kraftigt jordskælv på 9,3 på Richter-skalaen langs en subduktionszone, der løber vest for Sumatra. Den indo-australske plade subduceres ned under Sunda-pladen og Burma-mikropladen mod øst - begge tykkere plader. Burmapladen, hvorpå Andamanerne og Nicobarerne ligger, anses for at være en del af den store euroasiatiske plade (figuren nedenfor).
Efterskalv (gule cirkler) $i$ dagene efter hovedskcelvet (vist med stjerne). Pladernes placering og bevagelse er markeret med lilla, røde og sorte pile. De brune pile viser pladens bevagelse (ca. 60 mm/år) ved Sunda-graven. Vulkansk aktivitet er også vist. (Grafik: Forfatteren modificeret efter figur fra www.usgs.gov)

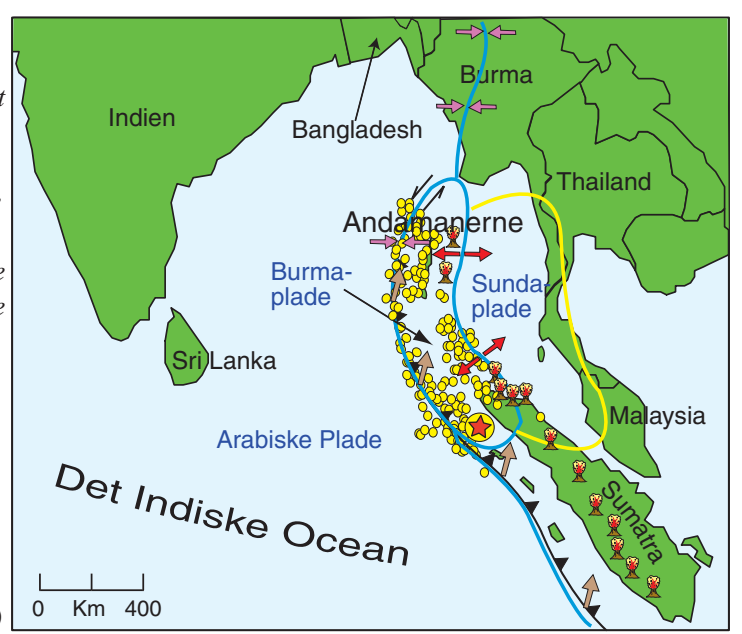




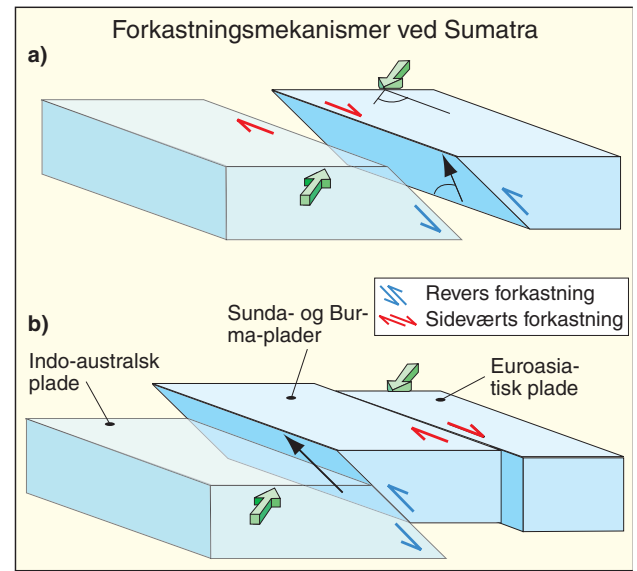

Forkastningsmodeller for pladerne i Det Indiske Ocean. Forklaring findes i teksten. (Grafik: Forfatteren)

Den subducerede indo-australske plade bevæger sig skævt - dvs. med en vinkel - i forhold til de to "overridende" Sunda- og Burma-plader. Som det ses på (a) (figuren ovenfor), kan bevægelsen ske ved en skæv forkastning, som består af to komponenterdels en revers komponent (markeret med de tynde blå pile) og dels en sideværts (strike-slip) forkastning (forskydning af den overridende plade - her mod højre) markeret med de tynde røde pile. De tykke, grønne pile markerer den skrå komponent. I (b) finder der kun en revers forkastning sted kombineret med en sideværts forkastning (som ved San Andreas) mellem de to bageste plader. Man mener, at den dominerende proces overvejende er som illustreret $i$ den nederste figur - dvs. en opdeling af forskydningen i to komponenter - en revers forkastning kombineret med en sideværts forkastning. Det to processer er tidsmæssigt og gegrafiskt adskilt, dvs. overskydningen finder ikke nødvendigvis sted samtidig med forkastningen sideværts.

Som beskrevet under Ocean-oceankollision udgør Sumatra, Andamanerne og Nicobarerne en øbue beliggende ved Sundagraven. Øbuen strækker sig fra Burma til Java. Der var dog ikke vulkanisme relateret til jordskælvet, selvom der ligger kendte vulkaner i øbuen fx Krakatau og Tambora., der har givet ophav til nogen af de bedst kendte og voldsommeste vulkanudbrud i verden.

\section{Aktivt område}

Der er blevet opbygget mange spændinger i forkastningszonen gennem ca. 200 år - primært i selve subduktionszonen og endvidere i hele området som følge af, at flere plader mødes. Da mængden af den opbyggede stress blev kritisk, resulterede det $i$ et jordskælv og talrige efterskælv heraf adskillige på over 7,0 på Richter-skalaen. Pga. den meget aktive pladebevægelse i området vil der altid forekomme jordskælv og vulkansk aktivitet, og det er derfor overordentligt sandsynligt, at der atter vil forekomme voldsomme jordskælv omkring Sumatra.

\section{Litteratur:}

Poster fra http://neic.usgs.gov

Skinner, B.J. \& Porter, S.C., 1999: The

Dynamic Earth

\section{Sumatra-jordskalvet tre gange kraftigere en hidtil antaget}

Jordskælvetd. 26.122004 visersig nu at være tre gange kraftigere end først antaget.

Det første bud på styrken af jordskælvet den 26. december ud for Sumatra var 8,9 på den åbne Richterskala. Et tal der efter få timer blev forhøjet til 9,0.

$\mathrm{Nu}$ har geologer ved Northwestern University regnet sig frem til, at skælvet faktisk var 9,3 Richter. Altså er tre gang større, end tidligere antaget.
Det er faktisk - de tragiske omstændigheder til trods - en glædelig nyhed. Et 9,3 Richter skælv forekommer nemlig rent statistisk noget sjældnere end et 9,0 Richter. Det betyder så igen, at risikoen for gentagelsen af den voldsomme 2. juledag tsunami i vores tid også er reduceret.

Det kraftigste jordskælv, der instrumentelt er registreret var på 9,5 Richter og rystede Chile den 22. maj 1960. 